引用格式: 任强,何春阳,黄庆旭,等. 中国北方农牧交错带贫困动态一一基于贫困距离指数的分析 [J]. 资源科学, 2018,40(2): 404-416. [Ren Q, He C Y, Huang Q X, et al. The poverty dynamics in the Agro-Pastoral Transitional Zone in Northern China : a multiscale perspective based on the poverty gap index[J]. Resources Science, 2018,40(2):404-416.] DOI :10.18402/resci.2018.02.16

\title{
中国北方农牧交错带贫困动态 基于贫困距离指数的分析
}

\section{任 强 $^{1,2}$,何春阳 ${ }^{1,3}$, 黄庆旭 ${ }^{1,3}$,刘志锋 ${ }^{1,3}$, 李经纬 ${ }^{1,2}$}

(1. 北京师范大学地表过程与资源生态国家重点实验室人与环境可持续研究中心, 北京 100875 ;

2. 北京师范大学地理科学学部减灾与应急管理研究院, 北京 100875 ;

3. 北京师范大学地理科学学部资源学院, 北京 100875)

摘 要: 科学准确地评估中国北方农牧交错带的贫困动态对该区的可持续发展具有重要意义。为此,本文采 用贫困距离指数,在整体、局部和旗县三个尺度上分析了该区 2000-2014年的贫困动态。结果表明,在县域尺度, 2000-2014 年中国北方农牧交错带所有贫困县均脱贫。全区贫困县减少了 167 个, 贫困县人口减少了 4569.76 万。 贫困缓解与经济发展密切相关。其中, 公共财政收入与脱贫县贫困距离指数相关性最大 $(R=-0.51, P<0.01)$ 。在快 速脱贫过程中, 该区居民收入分配的不公平加剧。脱贫地区城乡居民收入差距增长了 2.11 倍, 脱贫地区旗县间人 均收入的变异系数增长了 $41.67 \%$ 。因此,建议在中国北方农牧交错带进一步精准扶贫时,应该注意收入分配公平 问题, 减少贫富差距, 从而实现区域真正的可持续发展。

关键词: 中国; 北方农牧交错带; 贫困动态; 贫困距离指数; 贫困标准;收入分配公平; 精准扶贫; 可持续发展

DOI :10.18402/resci.2018.02.16

\section{1 引言}

贫困是指个人或家庭无法维持其基本物质需 求的生活状态 ${ }^{[1]}$ 。维持基本的物质需求是人类福祉 的基本方面,而提高人类福祉是可持续发展的最终 目标 ${ }^{[2]}$ 。因此, 消除贫困一直是可持续发展目标的 重要内容 ${ }^{[3-5]}$ 。中国北方农牧交错带是将中国东北、 华北农区与天然草地牧区分隔的一条重要生态过 渡带 ${ }^{[6,7]}$ 。由于生态环境脆弱和工业基础薄弱等原 因, 中国北方农牧交错带一直是中国贫困人口比较 集中的地区之一 ${ }^{[8,9]}$ 。2016 年 11 月, 国务院印发的 “十三五”脱贫攻坚规划指出, 要通过精准扶贫的方 式着力解决区域性贫困问题。而识别贫困和分析 贫困区域的动态变化是精准扶贫的基础, 也是科学 合理制定扶贫政策的前提 ${ }^{[10-12]}$ 。因此, 科学准确地
评估中国北方农牧交错带的贫困动态对该区域的 可持续发展具有重要意义。

近年来,已有学者开始从不同的时空尺度分析 中国北方农牧交错带的贫困格局与动态。例如， Chen 等计算了中国北方农牧交错带集中连片特困 区 2012 年的贫困特征 ${ }^{[13]}$; 杨振等计算了中国北方农 牧交错带主要省份 2014 年的农村贫困格局 ${ }^{[14]}$ 。现 有的贫困研究主要基于国家或者省级统计数据,而 县是中国贫困评估和扶持的基本组织单位 ${ }^{[11,15,16]}$ 。 因此,现有研究难以准确地反映中国北方农牧交错 带县级尺度的贫困动态。虽然,已有部分学者基于 县级数据进行了贫困评估研究, 比如在国家、集中 连片特困区和省级尺度的单时段研究 ${ }^{[17-199}$ 或者是县

收稿日期: 2017-03-20,修订日期: 2017-09-02

基金项目: 国家重点基础研究发展计划项目 (2014CB954302) ;国家自然科学基金委青年科学基金项目 (41501195)。 作者简介: 任强, 男, 山西运城人, 博士生, 研究方向为景观/区域可持续科学。E-mail: rq_1994@mail.bnu.edu.cn 通讯作者: 何春阳 ,E-mail: hcy@bnu.edu.cn 
级尺度的多时段的研究 ${ }^{[20]}$ 。但是, 现有研究仍缺乏 对中国北方农牧交错带不同尺度上贫困格局和动 态的整体和系统性的认识。

经济维度是贫困的最基本维度,通常用来反映 一个地区的绝对贫困状况, 是目前国内外各大组织 识别贫困的基本维度 ${ }^{[3,21]}$ 。贫困距离指数是贫困标 准线与人均收人之间差值。贫困距离指数为多尺 度和长时间地评估区域贫困动态提供了解决方 式 ${ }^{[21]}$, 再加上贫困距离指数易于计算, 可以从经济维 度简单直接地反映各尺度贫困状况, 因此已经被广 泛应用于不同尺度上的贫困格局和动态研究中 ${ }^{[22-24]}$ 例如, 在全球尺度上, Francisco 等基于贫困距离指 数分析了 2012 年的全球贫困人口分布 ${ }^{[25]}$; 在国家尺 度上, 梁汉媚等利用该指数评估了 2002-2009年中 国城市贫困人口动态变化与空间分布特征 ${ }^{[26]}$; 在省 级尺度上, 罗正文等基于该指数剖析了陕西省 1992-2011年贫困格局的动态变化 ${ }^{[27]}$ 。

本文的研究目的是从不同尺度上揭示中国北 方农牧交错带2000-2014 年的贫困动态。本文首 先基于国际贫困标准,计算了中国北方农牧交错带 各旗县 2000 年、 2010 年和 2014 年的贫困距离指 数。然后,在整体、局部和旗县三个尺度上分析了 该地区 2000-2014年的贫困动态。最后, 讨论了中 国北方农牧交错带贫困距离指数与人口、经济和基 础设施建设的关系, 并进一步探讨了脱贫过程中的 收人分配公平问题。

\section{2 研究区、数据与方法}

\section{1 研究区概况}

中国北方农牧交错带位于 $100^{\circ} \mathrm{E}-125^{\circ} \mathrm{E}$ 和 $34^{\circ} \mathrm{N}-49^{\circ} \mathrm{N}$ 之间, 地跨内蒙古、黑龙江、吉林、辽宁、 河北、山西、陕西、甘肃、宁夏和青海 10 个省 (自治 区) , 包括 205 个县 (旗、县级市及市辖区), 总面积约 为 73 万 $\mathrm{km}^{2}$ (图 1)。该区域地处半湿润大陆性季风 气候向干旱典型大陆性气候的过渡区, 年平均气温 $2 \sim 8^{\circ} \mathrm{C}$, 年平均降水量 $250 \sim 500 \mathrm{~mm}^{[6]}$ 。地形上, 中国 北方农牧交错带是东北、华北平原和黄土高原向内 蒙古高原、青藏高原的过渡带, 海拔由东北向西南 递增, 最低处不及 $200 \mathrm{~m}$, 最高处接近 $4500 \mathrm{~m}^{[28]}$ 。景 观在自然上表现为森林草原与灌木草原向荒漠草 原过渡, 在人文上表现为农区向牧区过渡 ${ }^{[6]}$ 。

根据自然环境特征和社会经济条件, 可以将中国

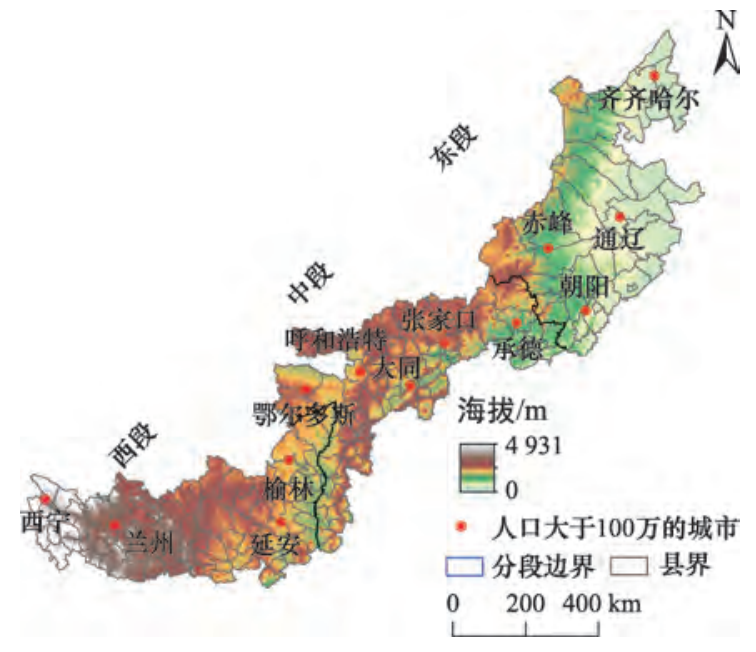

图 1 研究区示意

Figure 1 The study area

北方农牧交错带分为东中西三段,即三北交界区 (东 段)、晋陕甘黄土区(中段)和甘青宁黄土区(西段) $)^{[7]}$ 。 东段面积为 27 万 $\mathrm{km}^{2}$, 包括 40 个旗县和齐齐哈尔、 通辽、赤峰、朝阳 4 个人口大于 100 万的城市。中段 面积为 22 万 $\mathrm{km}^{2}$, 包括 81 个旗县和承德、张家口、呼 和浩特、大同和鄂尔多斯 5 个人口大于 100 万的城 市。西段面积为 24 万 $\mathrm{km}^{2}$, 包括 84 个旗县和兰州、 榆林、延安和西宁 4 个人口大于 100 万的城市 ${ }^{[29]}$ 。

\section{2 数据来源}

本研究中使用的数据包括人口数据、社会经济 统计数据和基础地理信息数据。

人口数据主要来自《中国人口普查数据集》[29,30] 和中国经济与社会发展统计数据库 ${ }^{[31]}$, 包括 2000 年、 2010 年和 2014 年农村居民和城镇居民人口数 据。2014年部分地区仅有总人口数,则通过联合国 法计算其农村居民和城镇居民人口数量 ${ }^{[32-34]}$ 。

社会经济统计数据来自 2000 年、2010 年和 2014 年《中国区域经济统计年鉴》 ${ }^{[35-37]}$ 和中国经济与 社会发展统计数据库 ${ }^{[31]}$,包括研究区各县 2000 年、 2010 年和 2014 年农村居民人均纯收人及城镇居民 人均可支配收人两个指标。2014年的部分数据来 自市级统计年鉴和县级政府工作报告。

基础地理信息数据主要为中国国家测绘中心 发布的中国矢量行政边界数据 ${ }^{[38]}$ 。

\section{3 研究方法}

\subsection{1 换算可比价}

为了消除价格变动对评估结果的影响, 参考 
Bernanke 的研究 ${ }^{[39]}$, 利用价格平减指数将各年份现 价人均收人转化为以 2014 年为基期的可比价人均 收人, 公式表示为:

$$
I_{2014}^{t}=I_{\text {real }}^{t} \cdot D_{2014}^{t}
$$

式中 $I_{2014}^{t}$ 表示以 2014 年为基期的第 $t$ 年可比价人均 收人; $I_{\text {real }}^{t}$ 表示第 $t$ 年现价人均收人; $D_{2014}^{t}$ 表示以 2014 年为基期的第 $t$ 年价格平减指数,价格平减指 数可通过查询《中国统计年鉴》 ${ }^{[40]}$ 获得。

\subsection{2 计算贫困距离指数}

根据 Batchelder 的研究 ${ }^{[4]}$, 本文计算了中国北方 农牧交错带各旗县 2000 年、2010年和 2014 年的贫 困距离指数。某年份旗县 $q$ 的贫困距离指数的计算 公式表示为:

$$
G_{q}=Z-I_{q}
$$

式中 $G_{q}$ 表示旗县 $q$ 的贫困距离指数; $Z$ 表示国际贫 困标准, 参考联合国可持续发展目标, 本文采用人 均 1.9 美元/天的国际贫困标准 ${ }^{[3]}$, 并将其换算为 4228 元人民币/年( 中国银行 2014 年 1 月 1 日外管局 中间价,一年按 365 天计算) ; $I_{q}$ 表示旗县 $q$ 的 2014 年可比价人均收人。 $I_{q}$ 的计算过程可以表示为:

$$
I_{q}=\frac{I_{q}^{\text {ural }} \cdot P_{q}^{\text {rural }}+I_{q}^{\text {urban }} \cdot P_{q}^{\text {urban }}}{P_{q}^{\text {rural }}+P_{q}^{\text {urban }}}
$$

式中 $I_{q}^{\text {rural }}$ 和 $I_{q}^{\text {urban }}$ 分别表示旗县 $q$ 的农村居民和城镇 居民的可比价人均收人; $P_{q}^{\text {rural }}$ 和 $P_{q}^{\text {urban }}$ 分别表示旗 县 $q$ 的农村人口和城镇人口。

2.3.3 分析2000-2010 年研究区贫困动态

参考联合国可持续发展目标 ${ }^{[3]}$, 本文首先依据 贫困距离指数, 对中国北方农牧交错带 205 个旗县 是否处于贫困状态进行了划分。 $G_{q}<0$ 表示处于非 贫困状态, $G_{q}>0$ 表示处于贫困状态。其次,参考了 梁汉媚等和陈烨烽等的研究 ${ }^{[26,42]}$, 根据贫困距离指 数的计算结果, 绘制了各旗县贫困距离指数的频数 分布直方图。依据直方图结果, 采用等比分割法, 将贫困划分为 3 个等级, 具体过程可以表示为:

$$
\text { Class }_{q}^{\text {poovery }}=\left\{\begin{array}{cc}
1 & 0 \leqslant G_{q}<0.2 Z \\
2 & 0.2 Z \leqslant G_{q}<0.4 Z \\
3 & 0.4 Z \leqslant G_{q}
\end{array}\right.
$$

式中 Class $_{q}^{\text {poerty }}$ 表示贫困县 $q$ 的贫困程度; 1 表示轻微 贫困,2表示中等贫困,3表示特别贫困。

最后通过贫困县的数量和贫困县的人口, 在整
体、局部和旗县三个尺度上分析了 2000 年中国北方 农牧交错带的贫困格局, 以及 2000-2014年该地区 的贫困动态。

\section{3 结果及分析}

\subsection{0 年中国北方农牧交错带的贫困格局}

2000 年, 在县域尺度,基于贫困距离指数,中国 北方农牧交错带超过一半的旗县处于贫困状态。 全区贫困县的数量达 167 个,占全区旗县总数的 $81.46 \%$ 。贫困县拥有人口 4569.76 万, 占全区人口 总量的 $70.60 \%$ 。其中, 城镇人口 745.73 万, 农村人 口 3824.03 万 $($ 表 1$) 。$

贫困县数量呈现自东向西递增格局。研究区 东段共有 30 个贫困县, 占全区贫困县总数的 $17.96 \%$ 。贫困县拥有人口 1268.92 万, 占全区贫困 县人口总量的 $27.77 \%$ 。中段共有 63 个贫困县, 占 全区贫困县总数的 $37.72 \%$ 。贫困县拥有人口 1363.09 万, 占全区贫困县人口总量的 $29.83 \%$ 。西 段共有 74 个贫困县，占全区贫困县总数的 $44.32 \%$ 。贫困县拥有人口 1937.75 万, 占全区贫困 县总人口的 $42.40 \%$ (表 1, 图 2)。

全区 167 个贫困县中, 中等贫困县数量最多。 中等贫困县数量为 70 个, 占贫困县总数的 $41.92 \%$ 。中等贫困县共有 1869.02 万人, 占贫困县 人口总量的 $40.90 \%$ 。特别贫困县和轻微贫困县的 数量分别为 58 个和 39 个, 分别占贫困县总数的 $34.73 \%$ 和 $23.35 \%$ (表 1 )。有 14 个贫困县的人口超 过了 50 万, 共包含 810 万人, 占贫困人口总数的 $17.75 \%$ 。其中, 特别贫困县有 5 个,包含人口 284.30 万。中等贫困县有 7 个, 共包含人口 418.56 万。轻 微贫困县有 2 个, 共包含人口 108.18 万(图 2 )。

\section{$3.22000-2014$ 年中国北方农牧交错带的贫困动态}

基于本研究, 在县域尺度, 按照贫困距离指数 进行计算,2014年中国北方农牧交错带所有贫困县 均脱贫。2000-2010年,全区贫困县数量从 167 个 减少到 10 个, 减少率为 $94.01 \%$ 。贫困县人口从 4569.76 万减少到 273.71 万, 减少率为 $94.01 \%$ 。 2010-2014年贫困县数量减少了 10 个,贫困县的人 口减少了 273.71 万(表2)。

从空间上看, 基于贫困距离指数, 2000-2010 年脱贫率自东到西递减。东段 2000-2010年贫困 
表 12000 年中国北方农牧交错带东中西段居民贫困指标分析

Table 1 The status of poverty in the APTZNC in 2000

\begin{tabular}{|c|c|c|c|c|c|}
\hline 贫困状态 & & 东段 & 中段 & 西段 & 全区 \\
\hline \multirow[t]{4}{*}{ 特别贫困 } & 贫困县数量(比例)* & $5(16.67 \%)$ & $19(30.16 \%)$ & $34(45.94 \%)$ & $58(34.73 \%)$ \\
\hline & 贫困县总人口 (比例) $* *$ & $248.08(19.55 \%)$ & $418.37(30.70 \%)$ & $956.26(49.35 \%)$ & $1622.72(35.51 \%)$ \\
\hline & 贫困县城镇人口/万人 & 25.94 & 55.35 & 77.04 & 158.33 \\
\hline & 贫困县农村人口/万人 & 222.15 & 363.02 & 879.22 & 1464.39 \\
\hline \multirow[t]{4}{*}{ 中等贫困 } & 贫困县数量 (比例)* & $16(53.33 \%)$ & $28(44.44 \%)$ & $26(35.14 \%)$ & $70(41.92 \%)$ \\
\hline & 贫困县总人口 (比例) $* * *$ & $679.42(53.54 \%)$ & $558.50(40.97 \%)$ & $631.11(32.57 \%)$ & $1869.02(40.90 \%)$ \\
\hline & 贫困县城镇人口/万人 & 149.08 & 101.35 & 88.49 & 338.93 \\
\hline & 贫困县农村人口/万人 & 530.33 & 457.14 & 542.62 & 1530.09 \\
\hline \multirow[t]{4}{*}{ 轻微贫困 } & 贫困县数量(比例)* & $9(30.00 \%)$ & $16(25.40 \%)$ & $14(18.92 \%)$ & $39(23.35 \%)$ \\
\hline & 贫困县总人口 (比例)** & $341.42(26.91 \%)$ & $386.22(28.33 \%)$ & $350.38(18.08 \%)$ & $1078.02(23.59 \%)$ \\
\hline & 贫困县城镇人口/万人 & 71.67 & 74.35 & 102.45 & 248.47 \\
\hline & 贫困县农村人口/万人 & 269.75 & 311.87 & 247.92 & 829.54 \\
\hline \multirow[t]{4}{*}{ 合计 } & 贫困县数量 & 30 & 63 & 74 & 167 \\
\hline & 贫困县总人口/万人 & 1268.92 & 1363.09 & 1937.75 & 4569.76 \\
\hline & 贫困县城镇人口/万人 & 246.69 & 231.05 & 267.99 & 745.73 \\
\hline & 贫困县农村人口/万人 & 1022.23 & 1132.04 & 1669.76 & 3824.03 \\
\hline
\end{tabular}

注: *括号中的比例表示不同贫困状态下的旗县数量占对应区域旗县总数的比例 $; * *$ *括号中的比例表示不同贫困状态下的旗县人口占对应区 域旗县总人口的比例。

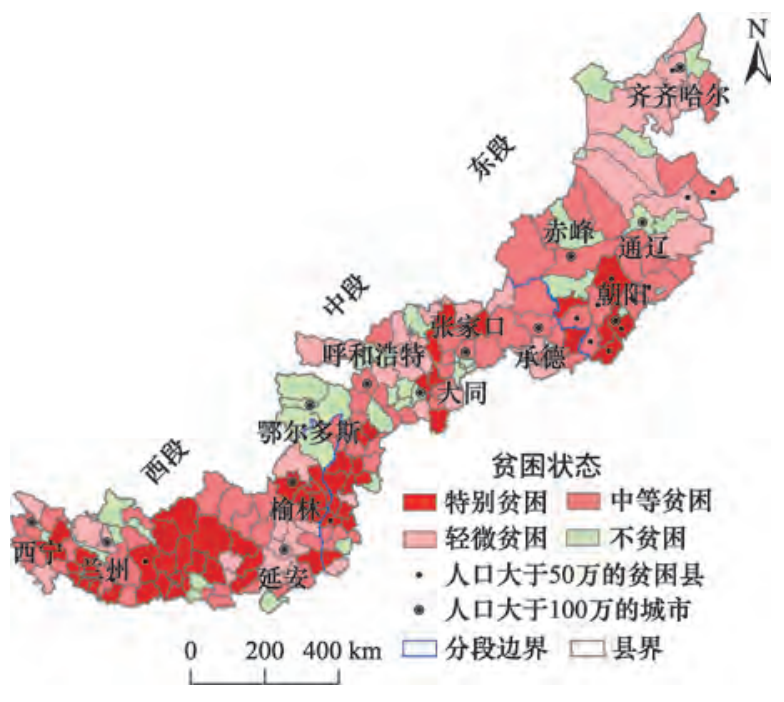

图 22000 年中国北方农牧交错带贫困格局

Figure 2 The poverty pattern in the APTZNC in 2000

县数量减少了 30 个, 脱贫率为 $100 \%$ 。人口减少了 1268.92 万人, 减少率为 $100 \%$ 。中段 2000-2010年 贫困县数量减少了 61 个,脱贫率为 $96.83 \%$ 。人口 减少了 1294.00 万人, 减少率为 $94.93 \%$ 。西段 2000-2010 年贫困县数量减少了 66 个, 脱贫率为 $89.19 \%$ 。人口减少了 1733.12 万人, 减少率为 $89.44 \%$ (表2,图3)。
从旗县尺度看, 基于贫困距离指数, 20002010 年, 中国北方农牧交错带特别贫困县数量和人 口均减少到 0 。中等贫困县和轻微贫困县数量分别 减少了 66 个和 33 个, 减少率分别为 $94.29 \%$ 和 $94.01 \%$ 。中等贫困县和轻微贫困县的人口分别减 少了 1761.07 万人和 912.25 万人,分别减少了 $94.22 \%$ 和 94.01\%。2010-2014年,特别、中等和轻微贫困 县数量分别减少了 0 个、 4 个和 6 个, 人口分别减少 了 0 人 107.95 万人和 165.76 万人 $($ 表 2$) 。 2000$ 年人 口超过 50 万的 14 个贫困县中, 有 13 个贫困县在 2000-2010年期间脱贫。2010-2014年,仅剩的轻 微贫困的山西省吕梁市石楼县也脱贫。

\section{3 贫困标准的变化对评估结果影响分析}

确定贫困标准是计算贫困距离指数的基础 ${ }^{[43]}$ 。 目前,除本研究采用的 1.9 美元/天贫困标准外,仍有 多个国际贫困标准在相关研究中得到应用 ${ }^{[21]}$ 。例 如,世界银行提出过 1 美元/天和 1.25 美元/天的国际 贫困标准 ${ }^{[4,45]}$ 。同时, 中国政府每年也会根据国情 不断更新中国的国家贫困标准 ${ }^{[4]}$ 。为此, 本文选取 了较为常用的五种贫困标准进一步衡量中国北方农牧 交错带 2000-2014 年贫困动态, 结果见表3( 见 409 页）。通过对比发现贫困标准的变化对贫困动态 
表2 $2000-2014$ 年中国北方农牧交错带贫困县和贫困县人口的变化数量

Table 2 Changes of number of poverty counties and population in poverty counties in the APTZNC from 2000 to 2014

(万人)

\begin{tabular}{|c|c|c|c|c|c|c|c|c|c|}
\hline \multirow[b]{2}{*}{ 时间 } & \multirow[b]{2}{*}{ 贫困状态 } & \multicolumn{2}{|c|}{ 东段 } & \multicolumn{2}{|c|}{ 中段 } & \multicolumn{2}{|c|}{ 西段 } & \multicolumn{2}{|c|}{ 全区 } \\
\hline & & $\begin{array}{c}\text { 贫困县数量 } \\
\text { 减少量 } \\
\end{array}$ & $\begin{array}{c}\text { 贫困县人口 } \\
\text { 减少量 }\end{array}$ & $\begin{array}{c}\text { 贫困县数量 } \\
\text { 减少量 } \\
\end{array}$ & $\begin{array}{c}\text { 贫困县人口 } \\
\text { 减少量 }\end{array}$ & $\begin{array}{c}\text { 贫困县数量 } \\
\text { 减少量 }\end{array}$ & $\begin{array}{c}\text { 贫困县人口 } \\
\text { 减少量 }\end{array}$ & $\begin{array}{c}\text { 贫困县数量 } \\
\text { 减少量 }\end{array}$ & $\begin{array}{c}\text { 贫困县人口 } \\
\text { 减少量 }\end{array}$ \\
\hline $2000-$ & 特别贫困 & 5 & 248.08 & 19 & 418.37 & 34 & 956.26 & 58 & 1622.72 \\
\hline \multirow[t]{3}{*}{ 2010年 } & 中等贫困 & 16 & 679.42 & 28 & 558.50 & 22 & 523.16 & 66 & 1761.07 \\
\hline & 轻微贫困 & 9 & 341.42 & 14 & 317.14 & 10 & 253.70 & 33 & 912.25 \\
\hline & 合计 & 30 & 1268.92 & 61 & 1294.00 & 66 & 1733.12 & 157 & 4296.04 \\
\hline $2010-$ & 特别贫困 & 0 & 0 & 0 & 0 & 0 & 0 & 0 & 0 \\
\hline \multirow[t]{3}{*}{ 2014年 } & 中等贫困 & 0 & 0 & 0 & 0 & 4 & 107.95 & 4 & 107.95 \\
\hline & 轻微贫困 & 0 & 0 & 2 & 69.09 & 4 & 96.68 & 6 & 165.76 \\
\hline & 合计 & 0 & 0 & 2 & 69.09 & 8 & 204.63 & 10 & 273.71 \\
\hline $2000-$ & 特别贫困 & 5 & 248.08 & 19 & 418.37 & 34 & 956.26 & 58 & 1622.72 \\
\hline \multirow[t]{3}{*}{ 2014年 } & 中等贫困 & 16 & 679.42 & 28 & 558.50 & 26 & 631.11 & 70 & 1869.02 \\
\hline & 轻微贫困 & 9 & 341.42 & 16 & 386.22 & 14 & 350.38 & 39 & 1078.02 \\
\hline & 合计 & 30 & 1268.92 & 63 & 1363.09 & 74 & 1937.75 & 167 & 4569.76 \\
\hline
\end{tabular}

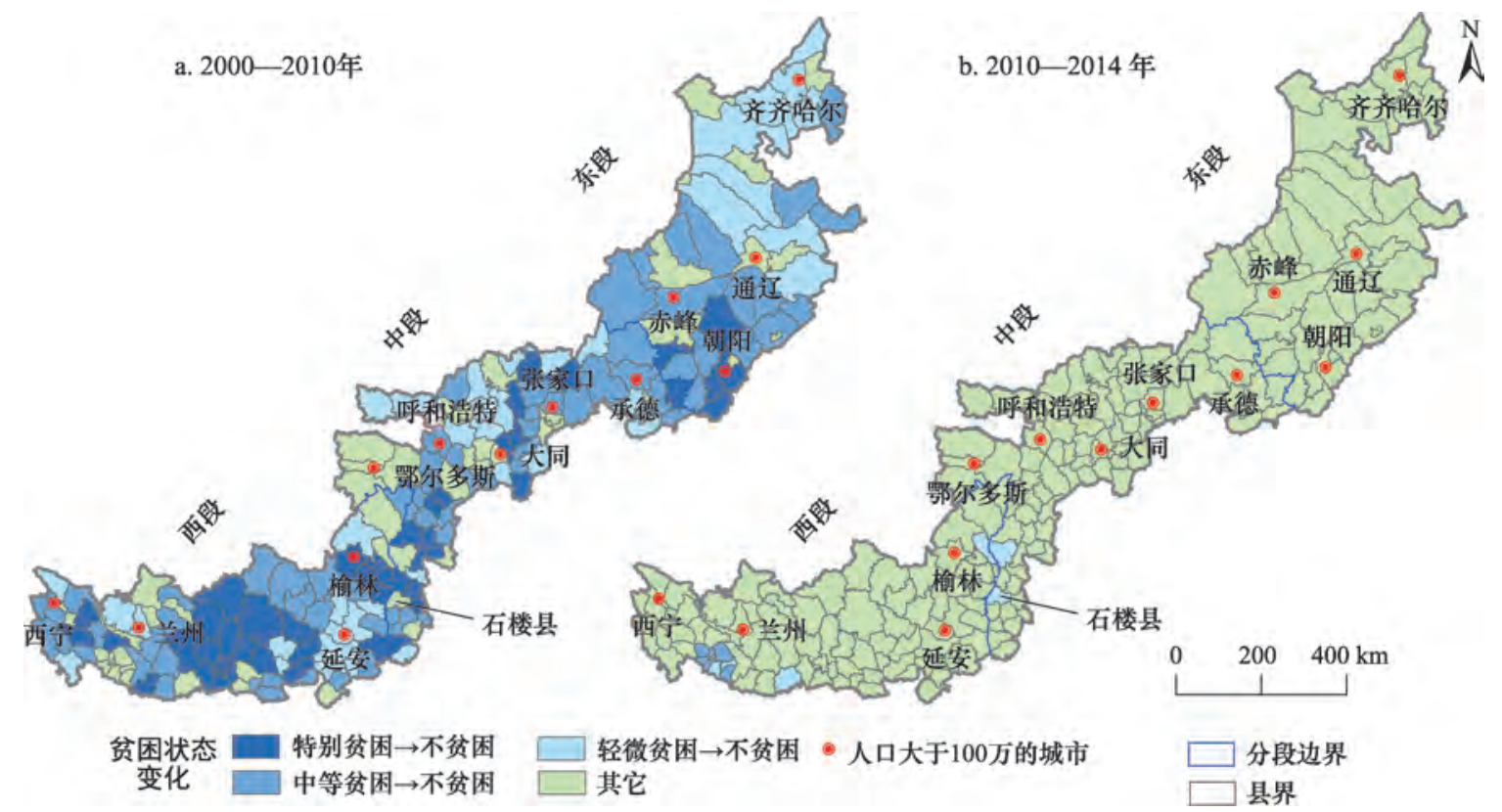

图32000-2014 年中国北方农牧交错带贫困状态变化

Figure 3 Changes of poverty in the APTZNC from 2000 to 2014

的评估影响很大。其中,采用2000-2007年668元/ 年的中国贫困标准评估的结果与本文评估的结果 差距最大。基于 668 元/年的中国国家贫困标准, 2000 年贫困县的数量和人口分别比本文评估结果 少 167 个和 4569.76 万人。2000-2014 年脱贫县的 数量和人口分别比本文评估结果少 167 个和 4569.76 万人 (表 3 )。由此可见, 科学地选择贫困标 准对于客观理解贫困格局和动态十分重要。
考虑到 1.9 美元/天国际贫困标准是世界银行通 过计算世界最贫困国家居民满足自身最低食品需 求时所需支出确定的,并被广泛应用于评估绝对贫 困人口 ${ }^{[21]}$ 。同时,该贫困标准是考虑了美元汇率波 动, 并依据国际最新购买力测定的,也是联合国可 持续发展目标采用的国际贫困标准, 是国际上最广 泛使用的最新制定的贫困标准之一 ${ }^{[47]}$ 。因此, 本文 选取 1.9 美元/天的贫困标准来进行中国北方农牧交 
表 3 不同贫困标准下中国北方农牧交错带的贫困县和贫困县人口数量 (万人)

Table 3 The impacts of different poverty lines on the number of poverty counties and their population (unit: 10000 persons)

\begin{tabular}{|c|c|c|c|c|c|}
\hline \multirow{2}{*}{ 贫困标准 } & \multirow{2}{*}{ 贫困线(元/年) } & \multicolumn{2}{|c|}{ 2000年贫困状态 } & \multicolumn{2}{|c|}{ 2000-2014年贫困动态 } \\
\hline & & 旗县数量 ${ }^{(1)}$ & 人口 ${ }^{(1)}$ & 旗县数量 ${ }^{(1)}$ & 人口 ${ }^{\mathbb{1}}$ \\
\hline 2000-2007年中国贫困标准 ${ }^{2}$ & 668 & -167 & -4569.76 & -167 & -4569.76 \\
\hline 2008-2010 年中国贫困标准 ${ }^{3}$ & 1222 & -166 & -4514.42 & -166 & -4514.42 \\
\hline 2011年中国贫困标准 & 2300 & -124 & -3381.20 & -124 & -3381.20 \\
\hline 1 美元/天的国际贫困标准 & 2225 & -130 & -3536.38 & -130 & -3536.38 \\
\hline 1.25 美元/天的国际贫困标准 & 2782 & -85 & -2394.02 & -85 & -2394.02 \\
\hline
\end{tabular}

注: (1)本栏使用不同贫困标准评估结果与 1.9 美元/天贫困标准评估结果的差值来反映不同贫困标准对评估结果的影响; 2)因 2000-2007 年中国国家标准变动较小,本文将其视为一个贫困标准,贫困线为该时段份贫困线均值; 3)因 2008-2010年中国国家标准变动较小,本文将 其视为一个贫困标准,贫困线为该时段份贫困线均值。

错带的贫困评估, 是具有合理性的。

参考 $\mathrm{Yu}$ 和 $\mathrm{Liu}$ 的方法 ${ }^{[15,17]}$, 本文通过对比不同 年份国家划定的贫困县 (区) 和非贫困县 (区) 的贫困 距离指数的差异, 来检验本文结果的有效性(表 4$)$ 。 具体来看,国家级贫困县与非国家级贫困县之间的 贫困距离指数存在显著性差异。其中,国家级贫困 县与非国家级贫困县之间的贫困距离指数的差异性 在 2010 年最大,$t$ 检验值为 $-8.066(P<0.01)$ 。2014年 次之, $t$ 检验值为 $-7.892(P<0.01)$ 。2000 年最小, $t$ 检 验值为 $-7.074(P<0.01)$ 。集中连片特困区内的旗县 和非集中连片特困区内的旗县之间的贫困距离指数 也存在显著性差异。集中连片特困区内的旗县和非 集中连片特困区内的旗县之间的贫困距离指数的 差异性在 2000 年最大, $t$ 检验值为 $-10.688(P<0.01)$ 。 结果表明,本文评估结果与国家基本政策判断基本 一致。因此,本文采用的评估方法是合理的。

\section{4 贫困缓解的影响因素及脱贫过程中 的收入分配差距分析}

\section{1 贫困缓解的关键影响因素}

国家的扶贫政策在中国北方农牧交错带脱贫 过程中扮演着重要的角色 ${ }^{[88}($ 表 5)。2000-2010年, 中国经历了大规模扶贫阶段。2001年6月,国务院 印发了《中国农村扶贫开发纲要 (2001-2010)》》22], 强调要提高贫困地区的经济状况,解决贫困人口的 温饱问题。在一系列扶贫政策的保障下,有力地促 进了贫困地区县域经济的发展,极大地提高了居民 的人均收人水平 ${ }^{[22]}$ 。本文研究结果也显示, 在 2000-2010年间, 中国北方农牧交错带经济维度上 的脱贫成效显著。在县域尺度,按照贫困距离指数, 167 个贫困县中有 157 个县脱贫, 脱贫率达 $94.01 \%$ 。 但是, 研究区在脱贫过程中收人分配不公平加剧。

表4 贫困距离指数对于识别国家划定的贫困县的有效性

Table 4 The validation of the poverty gap index for distinguishing the poverty counties determined by the government

\begin{tabular}{|c|c|c|c|c|c|}
\hline \multirow{2}{*}{ 时间 } & \multirow{2}{*}{ 分类 } & \multicolumn{4}{|c|}{ 贫困距离指数/元 } \\
\hline & & 国家级贫困县 & 非国家级贫困县 & 集中连片特困区 & 非集中连片特困区 \\
\hline \multirow[t]{3}{*}{ 2000年 } & 平均值 & 1438.54 & -117.69 & 1434.44 & 241.92 \\
\hline & 标准差 & 827.82 & 1863.47 & 977.69 & 1735.60 \\
\hline & $t$ 检验结果 & \multicolumn{2}{|c|}{ 存在显著性差异, $t=-7.074 * *$} & \multicolumn{2}{|c|}{ 存在显著性差异, $t=-10.688^{* *}$} \\
\hline \multirow[t]{3}{*}{ 2010年 } & 平均值 & -2837.99 & -7133.68 & -2248.31 & -7081.60 \\
\hline & 标准差 & 2073.60 & 4707.92 & 1858.33 & 4224.53 \\
\hline & $t$ 检验结果 & \multicolumn{2}{|c|}{ 存在显著性差异, $t=-8.066^{* * *}$} & \multicolumn{2}{|c|}{ 存在显著性差异, $t=-9.816^{* * *}$} \\
\hline \multirow[t]{3}{*}{ 2014年 } & 平均值 & -5725.48 & -11043.22 & -5105.36 & -10874.14 \\
\hline & 标准差 & 2773.40 & 5902.57 & 2633.09 & 5383.78 \\
\hline & $t$ 检验结果 & \multicolumn{2}{|c|}{ 存在显著性差异, $t=-7.892^{* * *}$} & \multicolumn{2}{|c|}{ 存在显著性差异, $t=-6.098^{* * *}$} \\
\hline
\end{tabular}

注: ${ }^{* *} P<0.01$ 。 
表 52000 - 2014 年国家扶贫政策与中国北方农牧交错带脱贫状况

Table 5 Major poverty alleviation policies in China and poverty alleviation in APTZNC from 2000 to 2014

\begin{tabular}{|c|c|c|}
\hline & 2000-2010年 & 2010-2014年 \\
\hline 阶段划分 & 大规模扶贫阶段 & 针对性扶贫阶段 \\
\hline 核心文件 & 《中国农村扶贫开发纲要(2001-2010)》 & 《中国农村扶贫开发纲要(2010-2020)》 \\
\hline 扶贫重点 & 中西部少数民族地区、革命老区、边疆地区和特困地区 & 集中连片特困区中的贫困重点县 \\
\hline \multirow[t]{3}{*}{ 奋斗目标 } & 1)提高贫困地区经济状况 & 1)推进贫困地区 (特别是集中连片特困区) 经济发展 \\
\hline & 2)解决贫困人口温饱问题 & 2)保障贫困地区人均收人高于区域平均水平 \\
\hline & & 3)缩小贫富差距 \\
\hline 脱贫县数量(脱贫率) & 157 个 $(94.01 \%)$ & 10 个 $(100 \%)$ \\
\hline 城乡收人差距变 & 5 925元/年(132.99\%) & 3489 元/年 $(33.61 \%)$ \\
\hline 化量(变化率) & & \\
\hline 贫困县间人均收人的变 & $0.11(47.17 \%)$ & $-0.02(-6.02 \%)$ \\
\hline 异系数变化量(变化率) & & \\
\hline
\end{tabular}

2000-2010年,脱贫县的城乡居民收人差距增加了 1.33 倍,旗县间的人均收人差异增长了 $47.17 \%$ 。

2010 年迄今,中国正处于针对性扶贫阶段。针 对受生态环境等因素限制而发展缓慢的贫困地区 和脱贫过程中日益增大的贫富差距问题,2011年 11 月国务院印发了《中国农村扶贫开发纲要 $(2011-$ 2020 年) $\rangle^{[49]}$ 。纲要指出要对集中连片特困区和重 点贫困区开展针对性脱贫工作。同时还要求保障 贫困县人均收人增长高于区域平均水平, 以减少贫 富差距。从本研究可以看出,中国北方农牧交错带 在经济维度上已经基本脱贫, 脱贫县的人均收人增 长高于区域平均水平, 旗县间的人均收人差距也有 减少。从 2010-2014年, 在县域尺度,按照贫困距 离指数, 中国北方农牧交错带仅有的 10 个贫困县均 脱贫。脱贫县人均收人从 3629.70 元增加到 6042.48 元,增长了 $66.47 \%$, 快于同期区域的人均收人增长 (34.03\%)。同时, 2010-2014年旗县间的人均收人 差异也减少了 $6.02 \%$ 。城乡居民收人差距增长趋势 虽然有所减缓，但是仍在增加，增加了 $33.61 \%$ 。

同时,本文还进一步研究了人口、经济和基础 设施建设三大类 12 个指标与脱贫县贫困距离指数 之间的关系 ${ }^{[00-52]}$,如表 6 所示。分析发现, 经济类指 标与脱贫县贫困距离指数的相关性普遍较高, 均呈 负相关关系 (表 6)。其中, 公共财政收人与脱贫县 贫困距离指数相关性最大, 相关系数达 $-0.508(P<$ $0.01)$ 。基础设施建设类指标也与脱贫县贫困距离 指数均呈现显著负相关关系。其中, 年末金融机构
各项贷款余额与脱贫县的贫困距离相关性最大, 相 关系数达 $-0.360(P<0.01)$ 。人口类指标与脱贫县贫 困距离指数呈显著相关关系。其中,城镇人口数量 与脱贫县的贫困距离呈显著负相关关系, 相关系数 达 $-0.495(P<0.01)$ 。农村人口数量与脱贫县的贫困 距离呈显著正相关关系, 相关系数达 $0.247(P<0.01)$ 。

区域尺度的对比结果显示, 脱贫县贫困距离指 数与人口、经济和基础设施建设类指标的相关关系 具有地区差异性。例如,东段脱贫县贫困距离指数 与第一产业增加值显著相关 $(r=-0.447, P<0.01)$, 与 基础设施建设类各指标相关性均不显著。相反, 中 段和西段脱贫县贫困距离指数与第一产业增加值 之间的相关关系并不显著,但是与基础设施建设类 各指标相关性均通过了显著性检验, 相关系数介 于- 0.412 和 -0.312 之间 $(P<0.01)$

\section{2 脱贫过程中的收入分配不公平加剧}

收人分配公平有利于优化经济结构,保障脱贫 过程中社会健康持续发展 ${ }^{[53-55]}$ 。因此本文采用了城 乡居民收人差、城乡居民收人比和各旗县间人均收 人的变异系数 3 个指标进一步考察了中国北方农牧 交错带脱贫过程中的收人公平问题 ${ }^{[56-59]}$ 。

研究结果显示, 在快速脱贫过程中,中国北方 农牧交错带居民的收人分配不公平加剧(表 7)。中 国北方农牧交错带脱贫过程中的城乡居民收人差 增加。全区脱贫县的城乡居民人均收人差从 2000 年的 4455.27 元增加到 2014 年的 13868.90 元, 增长 了 2.11 倍。脱贫县的城乡居民收人差增长率自东 
表 6 贫困距离指数与社会经济因素的相关性分析

Table 6 The relationship between the poverty gap index and socioeconomic indices

\begin{tabular}{llcccc}
\hline & 指标 & 全区 & 东段 & 中段 & 西段 \\
\hline 人口类 & 总人口数量 & $-0.157^{*}$ & $-0.383^{*}$ & -0.086 & $-0.147^{*}$ \\
& 城镇人口数量 & $-0.495^{* *}$ & $-0.446^{*}$ & $-0.496^{* *}$ & $-0.505^{* *}$ \\
& 农村人口数量 & $0.247^{* *}$ & 0.247 & $0.266^{*}$ & $0.241^{* *}$ \\
经济类 & 地区生产总值 & $-0.463^{* *}$ & $-0.464^{* *}$ & $-0.438^{* *}$ & $-0.485^{* *}$ \\
& 第一产业增加值 & -0.058 & $-0.447^{*}$ & -0.164 & -0.067 \\
& 第二产业增加值 & $-0.483^{* *}$ & -0.345 & $-0.432^{* *}$ & $-0.497^{* *}$ \\
& 第三产业增加值 & $-0.378^{* *}$ & $-0.483^{* *}$ & $-0.448^{* *}$ & $-0.398^{* *}$ \\
& 规模以上工业总产值 & $-0.365^{* *}$ & -0.350 & $-0.316^{*}$ & $-0.385^{* *}$ \\
& 规模以上工业企业单位数 & $-0.361^{* *}$ & $-0.447^{*}$ & $-0.344^{* *}$ & $-0.435^{* *}$ \\
& 公共财政收人 & $-0.508^{* *}$ & $-0.484^{* *}$ & $-0.444^{* *}$ & $-0.528^{* *}$ \\
& 固定资产投资 & $-0.274^{* *}$ & -0.193 & $-0.412^{* *}$ & $-0.312^{* *}$ \\
& 年末金融机构各项贷款余额 & $-0.360^{* *}$ & -0.286 & $-0.391^{* *}$ & $-0.365^{* *}$ \\
\hline 基础设施建设类 & & & & \\
& & &
\end{tabular}

注: $* P<0.05, * * P<0.01$ 。

表 $72000-2014$ 年中国北方农牧交错带脱贫地区城乡居民收入差距变化

Table 7 Changes in the difference of incomes between urban and rural residents in the APTZNC from 2000 to 2014

(元,\%)

\begin{tabular}{|c|c|c|c|c|c|c|c|c|}
\hline \multirow{2}{*}{ 区域 } & \multicolumn{2}{|c|}{ 城乡居民收人差 } & \multicolumn{2}{|c|}{ 城乡居民收人差变化 } & \multicolumn{2}{|c|}{ 城乡居民收人比 } & \multicolumn{2}{|c|}{ 城乡居民收人比变化 } \\
\hline & 2000 年 & 2014年 & 2000-2014年变化量 & 变化率 & 2000年 & 2014年 & 2000-2014年变化量 & 变化率 \\
\hline 全区 & 4455.27 & 13868.90 & 9413.62 & 211.29 & 3.14 & 2.93 & -0.21 & -6.69 \\
\hline 东段 & 4358.25 & 11104.74 & 6746.49 & 154.80 & 3.05 & 2.27 & -0.78 & -25.57 \\
\hline 中段 & 4802.01 & 13291.92 & 8489.91 & 176.80 & 3.29 & 3.01 & -0.28 & -8.51 \\
\hline 西段 & 4230.80 & 16440.95 & 12210.15 & 288.60 & 3.06 & 3.52 & 0.46 & 15.03 \\
\hline
\end{tabular}

向西呈递增格局。研究区东段的城乡居民收人差 从 2000 年的 4358.25 元增长到 2014 年的 11104.74 元, 增长了 1.55 倍。中段的收人差从 2000 年的 4802.01 元增加到 2014 年的 13291.92 元, 增加了 1.77 倍。西段的收人差从 2000 年的 4230.80 元增加 到2014年的 16440.95 元, 增加了 2.89 倍。

进一步分析发现, 在脱贫过程中, 中国北方农 牧交错带城乡收人比减少, 说明城乡收人相对差距 在降低。中国北方农牧交错带脱贫县的城乡收人 比从 2000 年的 3.14 下降到 2014 年的 2.93 , 减少了 $6.62 \%$ 。但值得注意的是,西段脱贫县的城乡收人 比增加。西段脱贫县的城乡收人比从 2000 年的 3.06 增加到 2014 年的 3.52 , 增长了 $15.83 \%$ 。东段脱 贫县城乡收人比从 2000 年的 3.05 下降到 2014 年的 2.27 , 减少了 $25.57 \%$ 。中段脱贫县城乡收人比从 2000 年的 3.29 下降到 2014 年的 3.01 , 减少了 $8.51 \%$ 。因此,西段在脱贫过程中,更应该注意提升
农村居民收人,以确保城乡协调发展。

中国北方农牧交错带脱贫过程中旗县间的人 均收人差异呈先增加后降低趋势。表 8 显示, 脱贫 旗县人均收人的变异系数从 2000 年的 0.24 增加到 2010 年的 0.36 , 后降低到 2014 年的 0.34 , 整体上增 加了 0.1 , 增长了 $41.67 \%$ 。其中, 西段脱贫旗县人均 收人的变异系数变化最大。西段脱贫旗县人均收 人的变异系数从 2000 年的 0.27 增加到 2010 年的 0.46 , 后降低到 2014 年的 0.45 , 整体上增加了 0.18 , 增 加了 $66.67 \%$ 。中段脱贫旗县人均收人的变异系数 从 2000 年的 0.23 增加到 2010 年的 0.29 , 后降低到 2014 年的 0.24 , 整体上增加了 0.01 , 增加了 $4.35 \%$ 。 东段脱贫旗县人均收人的变异系数变化平缓。

\section{5 结论与展望}

中国北方农牧交错带是中国贫困人口的主要 分布区域之一。在国家政策的指导下,中国北方农 牧交错带经济维度上的脱贫成效显著。在县域尺 
表 $82000-2014$ 年中国北方农牧交错带脱贫地区居民人均收入的差异变化

Table 8 Changes of the difference of per-capita incomes among the out-of-poverty counties in the APTZNC from 2000 to 2014

\begin{tabular}{|c|c|c|c|c|c|c|}
\hline \multirow{2}{*}{ 区域 } & \multicolumn{3}{|c|}{ 变异系数 } & \multicolumn{3}{|c|}{ 变异系数变化 } \\
\hline & 2000年 & 2010年 & 2014年 & 2000-2010年变化量 & 2010-2014年变化量 & 2000-2014年变化量 \\
\hline 全区 & 0.24 & 0.36 & 0.34 & 0.12 & -0.02 & 0.10 \\
\hline 东段 & 0.18 & 0.17 & 0.18 & -0.01 & 0.01 & 0.00 \\
\hline 中段 & 0.23 & 0.29 & 0.24 & 0.06 & -0.05 & 0.01 \\
\hline 西段 & 0.27 & 0.46 & 0.45 & 0.19 & -0.01 & 0.18 \\
\hline
\end{tabular}

注: 参考陈培阳等 ${ }^{[57}$ 的研究, 本文采用各旗县人均收人的变异系数衡量不同旗县之间的人均收人差异。变异系数通过相应区域各旗县人 均收人标准差和平均数的比计算。

度,按照贫困距离指数进行计算, 2000-2014 年中 国北方农牧交错带所有贫困县均脱贫。全区脱贫 县减少了 167 个,贫困县人口减少了 4569.76 万人。 通过对脱贫的关键影响因素分析,发现贫困缓解与 经济发展密切相关。经济类指标与脱贫县贫困距 离指数的相关性普遍较高, 均呈负相关关系。其 中,公共财政收人与脱贫县贫困距离指数相关性最 大,相关系数达 $-0.51(P<0.01)$ 。

虽然在县域尺度上中国北方农牧交错带的脱 贫效果显著,但是在村域或个体层面,贫困问题依 旧严重 ${ }^{[00]}$ 。2013 年 11 月, 习近平总书记在湘西调研 时提出“精准扶贫”的理念。2013 年12月,国务院印 发《关于创新机制扎实推进农村扶贫开发工作的意 见 $\rangle^{[0]}$, 提出要建立精准扶贫工作机制, 逐村逐户制 定帮扶措施。2014年, 国务院扶贫办《关于印发〈建 立精准扶贫工作机制实施方案 $\rangle$ 的通知》 ${ }^{[61}$ 和《关于 印发〈扶贫开发建档立卡工作方案〉的通知》策两个 文件的出台,标志着中国建立精准扶贫工作机制在 全国正式启动实施。未来,中国应更加关注个体层 面的贫困分析。同时,在 2000-2014年快速脱贫的 过程中,中国北方农牧交错带居民的收人分配不公 平加剧。因此,在扶贫过程中也应该注意贫富悬殊 问题,要重视分配公平,通过城乡对口援建等手段, 统筹区域经济发展,缩小贫富差距,科学扶贫。

本研究仍然存在一些不足。首先, 本文采用贫 困距离指数仅能衡量经济维度的贫困状态, 难以全 面系统地衡量区域各个维度的贫困状态。而国家 贫困县的认定,在考虑经济维度的基础上, 同时考 虑了健康、教育、环境和区域特征等多方面因素。 因此,本文评估结果与实际存在差距。第二, 受数
据可获取性限制,采用县级数据进行指标运算,难以 解释居民个体的贫困状态。未来可以深人研究适合 中国北方农牧交错带的指标,采用多维贫困理论全 面衡量区域贫困状态 ${ }^{[3-64]}$; 另外可以针对典型县采 用实地调研等手段,分析居民个体层面贫困特征, 也可以通过遥感检测等方法 ${ }^{[65,66]}$, 获得更长时间和 大尺度的贫困动态。

\section{参考文献(References)：}

[1] 国家统计局《中国城镇居民贫困问题研究》课题组. 中国城镇 居民贫困问题研究 [J]. 统计研究, 1991, (6): 12-18. [The Research Group on the Poverty of Urban Residents in China, National Bureau of Statistics of China. Studies on the poverty of urban residents in China[J]. Statistical Studies, 1991, (6): 12-18. ]

[2] 邬建国, 郭晓川, 杨劼, 等. 什么是可持续性科学? [J]. 应用生态 学报, 2014, 25(1): 1-11. [Wu J G, Guo X C, Yang J, et al. What is sustainability science? [J]. Chinese Journal of Applied Ecology, 2014, 25(1): 1-11. ]

[3] United Nations, General Assembly. Transforming Our World: The 2030 Agenda for Sustainable Development [R]. New York: United Nations, 2015.

[4] Millennium Ecosystem Assessment (MEA). Ecosystems and Human Well- being: Synthesis [R]. Washington DC: Island Press, 2005.

[5] United Nations, General Assembly. United Nations Millennium Declaration[R]. New York: United Nations, 2000.

[6]史培军. 中国北方农牧交错带土地利用时空格局与优化模拟 [M]. 北京: 科学出版社, 2009. [Shi P J. Spatiotemporal Pattern and Optimization Simulation of Land Use in the Agro-Pastoral Transitional Zone in Northern China[M]. Beijing: Science Press, 2009. ]

[7] 王静爱, 徐霞, 刘培芳. 中国北方农牧交错带土地利用与人口 
负荷研究 [J]. 资源科学, 1999, 21(5): 19-24. [Wang J A, Xu X, Liu P F. Land use and land carrying capacity in ecotone between agriculture and animal husbandry in northern China[J]. Resources Science, 1999, 21(5): 19-24. ]

[8] 裴银宝, 刘小鹏, 李永红, 等. 六盘山特困片区村域空间贫困调 查与分析-以宁夏西吉县为例[J]. 农业现代化研究, 2015, 36(5): 748-754. [Pei Y B, Liu X P, Li Y H, et al. Investigation and analysis of villages in extreme spatial poverty in Liupan Mountain contiguous areas: A case study of Xiji, Ningxia Province[J]. Research of Agricultural Modernization, 2015, 36(5): 748-754. ]

[9] 刘小鹏, 苏胜亮, 王亚娟, 等. 集中连片特殊困难地区村域空间 贫困测度指标体系研究 [J]. 地理科学, 2014, 34(4):447-453. [Liu X P, Su S L, Wang Y J, et al. The index system of spatial poverty of village level to monitor in concentrated contiguous areas with particular difficulties[J]. Scientia Geographica Sinica, 2014, 34(4): 447-453. ]

[10] 傅伯杰, 于丹丹, 吕楠. 中国生物多样性与生态系统服务评估指 标体系[J]. 生态学报, 2017, 37(2): 341-348. [Fu B J, Yu D D, Lv N. An indicator system for biodiversity and ecosystem services evaluation in China[J]. Acta Ecologica Sinica, 2017, 37(2):341-348. ]

[11］国务院扶贫开发领导小组办公室. 国务院关于印发 “十三五”脱 贫攻坚规划的通知 [EB/OL]. (2016-12-03)[2017-09-01]. http:// www.cpad.gov.cn/art/2016/12/3/art_46_56101.html. [The State Council Leading Group Office of Poverty Alleviation and Development. Notice of Issuance about the Poverty Alleviation Planning in China 's 13th Five-year Plan by the State Council [EB/OL]. (2016-1203) [2017- 09- 01]. http://www.cpad.gov.cn/art/2016/12/3/art_46_ 56101.html.]

[12] 汪三贵, 郭子豪. 论中国的精准扶贫 [J]. 贵州社会科学, 2015, (5): 147-150. [Wang S G, Guo Y H. Discussion of poverty alleviation in China[J]. Guizhou Social Science, 2015, (5): 147-150. ]

[13] Chen W, Feng D, Chu X. Study of poverty alleviation effects for Chinese fourteen contiguous destitute areas based on entropy method[J]. International Journal of Economics \& Finance, 2015, doi: http://dx.doi.org/10.5539/ijef.v7n4p89.

[14] 杨振, 江琪, 刘会敏, 等. 中国农村居民多维贫困测度与空间格 局[J]. 经济地理, 2015, 35(12): 148-153. [Yang Z, Jiang Q, Liu H M, et al. Multi-dimensional poverty measure and spatial pattern of China's rural residents [J]. Economic Geography, 2015, 35(12): 148-153. ]

[15] Yu B, Shi K, Hu Y, et al. Poverty evaluation using NPP- VIIRS nighttime light composite data at the county level in China [J]. IEEE Journal of Selected Topics in Applied Earth Observations \& Remote Sensing, 2017, 8(3): 1217-1229.

[16] 刘彦随, 周扬, 刘继来. 中国农村贫困化地域分异特征及其精准 扶贫策略 [J]. 中国科学院院刊, 2016, (3): 269-278. [Liu Y S, Zhou Y, Liu J L. Regional differentiation characteristics of rural poverty and targeted poverty alleviation strategy in China [J]. Bulletin of Chinese Academy of Sciences, 2016, (3): 269-278. ]

[17] Liu Y, Xu Y. A geographic identification of multidimensional poverty in rural China under the framework of sustainable livelihoods analysis [J]. Applied Geography, 2016, 73:62-76.

[18] 王艳慧, 钱乐毅, 段福洲. 县级多维贫困度量及其空间分布格局 研究-以连片特困区扶贫重点县为例 [J]. 地理科学, 2013, 33 (12): 1489-1497. [Wang Y H, Qian L Y, Duang F Z. Multidimensional poverty measurement and spatial distribution pattern at the country scale: A case study on key country from national contiguous special poverty-stricken areas [J]. Scientia Geographica Sinica, 2013, 33(12): 1489-1497. ]

[19] 袁媛, 王仰麟, 马晶, 等. 河北省县域贫困度多维评估 [J]. 地理 科学进展, 2014, 33(1):124-133. [Yuan Y, Wang Y L, Ma J, et al. Multidimensional evaluation of county poverty degree in Hebei Province[J]. Progress in Geography, 2014, 33(1): 124-133. ]

[20] Rogers S. Betting on the strong: Local government resource allocation in China's poverty counties[J]. Journal of Rural Studies, 2014, 36: 197-206.

[21] Klasen S, Krivobokova T, Greb F, et al. International income poverty measurement: Which way now? [J]. The Journal of Economic Inequality, 2016, 14(2): 199-225.

[22] 中华人民共和国中央人民政府.《中国农村扶贫开发纲要 (2001-2010年)》. [EB/OL]. (2001-08-20)[2017-09-01]. http:// www.gov.cn/gongbao/content/2001/content_60922.htm. [ The State Council in the People's Republic of China. China's Rural Poverty Alleviation and Development Outline (2001-2010). [EB/OL]. (2001-08-20)[2017-09-01]. ]

[23] World Bank. Poverty in a Rising Africa [M]. Washington DC: World Bank Publications, 2015.

[24] 刘小鹏, 苏晓芳, 王亚娟, 等. 空间贫困研究及其对我国贫困地 理研究的启示 [J]. 干旱区地理, 2014, 37(1): 144-152. [ Liu X P, Su X F, Wang Y J, et al. Review on spatial poverty and deprivation and its enlightenments to poverty geography studies in China [J]. Arid Land Geography, 2014, 37(1): 144-152. ]

[25] Ferreira F H G, Chen S, Dabalen A, et al. A global count of the extreme poor in 2012: Data issues, methodology and initial results [J]. The Journal of Economic Inequality, 2016, 14(2): 1-32.

[26] 梁汉媚, 方创琳. 中国城市贫困人口动态变化与空间分异特征 探讨[J]. 经济地理, 2011, 31(10): 1610-1617. [Liang H M, Fang C L. The dynamic changes and spatial distribution of urban poverty in China[J]. Economic Geography, 2011,31(10): 1610-1617. ]

[27] 罗正文,薛东前. 陕西省农村贫困的动态变化研究[J]. 干旱区资 源与环境, 2015, 29(6): 39-44. [Luo Z W, Xue D Q. Poverty dynamics in rural Shaanxi[J]. Journal of Arid Land Resources and Environment, 2015, 29(6): 39-44. ]

[28] 赵哈林, 赵学勇, 张铜会, 等. 北方农牧交错带的地理界定及其 
生态问题[J]. 地球科学进展, 2002, 17(5): 739-747. [Zhao H L, Zhao X Y, Zhang T H, et al. Boundary line on agro-pasture zigzag zone in north China and its problems on eco-environment [J]. $A d$ vance in Earth Sciences, 2002, 17(5): 739-747. ]

[29] 国务院人口普查办公室. 中国 2010 年人口普查资料[M]. 北京: 中国统计出版社, 2012. [National Population Census Office of China. China 2010 Population Census Data[M]. Beijing: China Statistics Press, 2012.]

[30] 国务院人口普查办公室. 中国 2000 年人口普查资料 [M]. 北京: 中国统计出版社, 2002. [National Population Census Office of China. China 2000 Population Census Data[M]. Beijing: China Statistics Press, 2002. ]

[31] 中国知识基础设施工程. 中国经济与社会发展统计数据库 [EB/OL]. (2015- 12- 01) [2017- 09-01]. http://tongji.cnki.net/ kns55/.[National Knowledge Infrastructure of China. Statistical Database of Economic and Social Development [EB/OL]. (2015-1201)[2017-09-01]. http://tongji.cnki.net/kns55/. ]

[32] United Nations. Department of International Economic and Social Affairs. Patterns of Urban and Rural Population Growth[M]. New York: Oxford University Press, 1980.

[33] 周一星. 城市地理学[M]. 北京: 商务印书馆, 1995. [Zhou Y X. Urban Geography[M]. Beijing: The Commercial Press, 1995.$]$

[34] 尤鍂. 西部地区城镇化水平与经济人口发展变化研究-基于 2000-2010 年西部地区十二个省区面板数据[J]. 地理科学, 2015, 35(3): 268-274. [ You X. Change and relationship between the urbanizatio economy and population in western regions [J]. Scientia Geographica Sinica, 2015, 35(3): 268-274. ]

[35] 国家统计局. 中国区域经济统计年鉴-2001 [M]. 北京: 中国财 政经济出版社, 2003. [ National Bureau of Statistics of China. 2001 China Statistical Yearbook for Regional Economy[M]. Beijing: Chinese financial \& Economic Publishing House, 2003. ]

[36] 国家统计局. 中国区域经济统计年鉴-2010 [M]. 北京: 中国统 计出版社, 2011. [National Bureau of Statistics of China. 2010 China Statistical Yearbook for Regional Economy[M]. Beijing: China Statistics Press, 2011.

[37] 国家统计局. 中国区域经济统计年鉴-2014 [M]. 北京: 中国统 计出版社, 2015. [National Bureau of Statistics of China. 2014 China Statistical Yearbook for Regional Economy [M]. Beijing: China Statistics Press, 2015. ]

[38] 国家基础地理信息中心. 中国矢量行政边界数据 [EB/OL]. (2015- 12- 01) [2017- 09- 01]. http://ngcc.sbsm.gov.cn. [National Geomatics Center of China. Administrative Boundaries Data in China [EB/OL]. (2015-12-01) [2017-09-01]. http://ngcc.sbsm. gov.cn.]

[39] Bernanke B S, Mihov I. Measuring Monetary Policy[J]. The Quarterly Journal of Economics, 1998, 113(3): 869-902.

[40] 国家统计局. 中国统计年鉴-2015 [M]. 北京: 中国统计出版社,
2015. [National Bureau of Statistics of China. 2015 China Statistical Yearbook [M]. Beijing: China Statistics Press, 2015. ]

[41] Clark S, Hemming R, Ulph D. On indices for the measurement of poverty [J]. The Economic Journal, 1981, 91(362): 515-526.

[42] 陈烨烽, 王艳慧, 王小林. 中国贫困村测度与空间分布特征分 析 [J]. 地理研究, 2016, 35(12):2298-2308. [Chen Y F, Wang Y H, Wang X L. Measurement and spatial analysis of poverty-stricken villages in China [J]. Geographical Research, 2016, 35(12): 2298-2308. $]$

[43] 王萍萍. 中国贫困标准与国际贫困标准的比较[J]. 中国农村经 济, 2006, (12): 62-68. [Wang P P. The comparisons between the Chinese poverty standards and the international poverty standards [J]. Chinese Rural Economy, 2006, (12): 62-68. ]

[44] World Bank. World Development Report 1990: Poverty[M]. New York: Oxford University Press, 1990.

[45] Ravallion M, Chen S, Sangraula P. Dollar a day revisited[J]. Social Science Electronic Publishing, 2008, 23(2):163-184.

[46] 王小林. 贫困标准及全球贫困状况[J]. 经济研究参考, 2012, (55):41-50. [Wang X L. Poverty standards and the situation of global poverty[J]. Review of Economic Research, 2012, (55): 41-50. ]

[47] Dzanku F M, Jirström M, Marstorp H. Yield gap-based poverty gaps in rural Sub-Saharan Africa[J]. World Development, 2015, 67: $336-362$.

[48] Liu Y, Fang F, Li Y. Key issues of land use in China and implications for policy making[J]. Land Use Policy, 2014, 40(1): 6-12.

[49] 中华人民共和国中央人民政府. 中国农村扶贫开发纲要(20112020 年) [EB/OL]. (2011-12-15) [2017-09-01]. http://www.gov. cn/gongbao/content/2011/content_2020905.htm. [The State Counci in the People's Republic of China. The State Council China's Rural Poverty Alleviation and Development Outline (2011-2020) [EB/OL]. (2011-12-15)[2017-09-01]. http://www.gov.cn/gongbao/ content/2011/content_2020905.htm. ]

[50] Liu Y, Liu J, Zhou Y. Spatio-temporal patterns of rural poverty in China and targeted poverty alleviation strategies[J]. Journal of $R u$ ral Studies, 2017, 52: 66-75.

[51] Sun P, Xu Y Q, Yu Z L, et al. Scenario simulation and landscape pattern dynamic changes of land use in the Poverty Belt around Beijing and Tianjin: A case study of Zhangjiakou city, Hebei Province[J]. Journal of Geographical Sciences, 2016, 26(3): 272-296.

[52] Loayza N V, Raddatz C. The composition of growth matters for poverty alleviation[J]. Journal of Development Economics, 2010, 93(1): 137-151.

[53] You H, Zhang X. Sustainable livelihoods and rural sustainability in China: Ecologically secure, economically efficient or socially equitable?[J]. Resources Conservation \& Recycling, 2017, 120: 1-13.

[54] Tian X, Zhang X, Zhou Y, et al. Regional income inequality in China revisited: A perspective from club convergence[J]. Economic 
Modelling, 2016, 56: 50-58.

[55] Rodríguez-Pose A, Hardy D. Addressing poverty and inequality in the rural economy from a global perspective[J]. Applied Geography, 2015, 61: 11-23.

[56] 王雪妮, 孙才志. 1996-2008 年中国县级市减贫效应分解与空 间差异分析 [J]. 经济地理, 2011, 31(6): 888-894. [Wang X N, Sun C Z. The micro-perspective of economic geography research [J]. Economic Geography, 2011, 31(6): 888-894. ]

[57] 陈培阳, 朱喜钢. 基于不同尺度的中国区域经济差异 [J]. 地理 学报, 2012, 67(8): 1085-1097. [Chen P Y, Zhu X G. Regional inequalities in China at different scales[J]. Acta Geographica Sinica, 67(8): 1085-1097. ]

[58] 冯长春, 曾赞荣, 崔娜娜. 2000 年以来中国区域经济差异的时 空演变[J]. 地理研究, 2015, 34(2):234-246. [Feng C C, Zeng Z R, Cui N N. The economic disparities and their spatio-temporal evolution in China since 2000[J]. Geographical Research, 2015, 34 (2): 234-246. ]

[59] 王芳, 高晓路. 内蒙古县域经济空间格局演化研究[J]. 地理科 学, 2014, 34(7): 818-824. [Wang F, Gao X L. Spatial pattern evolvement of the economy in Inner Mongolia at the county level [J]. Scientia Geographica Sinica, 2014, 34(7): 818-824. ]

[60] 杨园园, 刘彦随, 张紫雯. 基于典型调查的精准扶贫政策创新及 建议 [J]. 中国科学院院刊, 2016, (3): 337-345. [Yang Y Y, Liu Y S, Zhang Z W. Study on policy innovation and suggestions of targeted poverty alleviation based on typical investigation[J]. Bulletin of Chinese Academy of Sciences, 2016, (3): 337-345.]

[61] 国务院. 关于印发《建立精准扶贫工作机制实施方案》的通知 [EB/OL]. (2014-05-26)[2017-09-01]. http://www.cpad.gov.cn/art/ 2014/5/26/art_50_23765.html. [ The State Council. Notice of Issuance about the Suggestions about Poverty Alleviation in Rural Areas by the Innovation of Mechanism [EB/OL]. (2014- 05-26) [2017-09- 01]. http://www.cpad.gov.cn/art/2014/5/26/art_50_23765. html.]

[62] 国务院. 国务院扶贫办关于印发《扶贫开发建档立卡工作方案》 的通知 [EB/OL]. (2014-04-11) [2017-09-01]. http://www.cpad. gov.cn/art/2014/4/11/art_50_23761.html. [The State Council. Notice of Issuance about the Targeted Poverty Alleviation Measures [EB/OL]. (2014-04-11)[2017-09-01]. http://www.cpad.gov.cn/art/ 2014/4/11/art_50_23761.html.]

[63] Labar K, Bresson F. A multidimensional analysis of poverty in China from 1991 to 2006[J]. China Economic Review, 2011, 22(4): 646-668.

[64] Alkire S, Foster J. Counting and multidimensional poverty measurement [J]. Journal of Public Economics, 2011, 95(7): 476-487.

[65] Jean N, Burke M, Xie M, et al. Combining satellite imagery and machine learning to predict poverty[J]. Science, 2016, 353(6301): 790-794.

[66] Pinkovskiy M, Salaimartin X. Lights, camera income! Illuminating the national accounts-household surveys debate[J]. Quarterly Journal of Economics, 2016, 131(2): 579-631. 


\title{
The poverty dynamics in the Agro-Pastoral Transitional Zone in Northern China : a multi-scale perspective based on the poverty gap index
}

\author{
REN Qiang ${ }^{1,2}$, HE Chunyang ${ }^{1,3}$, HUANG Qingxu ${ }^{1,3}$, LIU Zhifeng ${ }^{1,3}$, Li Jingwei ${ }^{1,2}$ \\ (1. Center for Human-Environment System Sustainability, State Key Laboratory of Earth Surface Processes and Resource \\ Ecology, Beijing Normal University, Beijing 100875, China; \\ 2. Academy of Disaster Reduction and Emergency Management, Faculty of Geographical Science, Beijing Normal University, \\ Beijing 100875, China; \\ 3. School of Natural Resources, Faculty of Geographical Science, Beijing Normal University, Beijing 100875, China)
}

\begin{abstract}
The Agro-Pastoral Transitional Zone in Northern China (APTZNC) is one of the most impoverished areas in China. Accurately assessing poverty dynamics in the APTZNC is of significance to regional sustainable development. We used the poverty gap index to investigate the dynamics of poverty in the APTZNC from 2000 to 2014 at three scales: regional, sub-regional and county scales. The results showed that all impoverished counties were lifted out of poverty from 2000 to 2014 based on the poverty gap index. At the county scale, the number of impoverished counties decreased by 167 from 2000 to 2014, and the population in impoverished counties decreased by 45.70 million. Specifically, the number of impoverished counties decreased from 167 in 2000 to 10 in 2010, a reduction of $94.01 \%$. The population in impoverished counties decreased from 45.70 million in 2000 to 2.73 million in 2010, a reduction of 94.03\%. From 2010 to 2014, the number of impoverished counties decreased by 10 and the population in impoverished counties decreased by 2.73 million. We also found that poverty alleviation from 2000 to 2014 was closely related with economic development. Among all indicators, public fiscal revenue had the highest correlation with poverty alleviation $(r=-0.51, P<0.01)$. Meanwhile, difference in incomes between urban and rural residents in the out- of-poverty areas increased from $4455.27 \mathrm{CNY}$ in 2000 to 11 104.71 CNY in 2014, a 2.11-fold increase. The coefficient of variation in per-capita rural income among out-of-poverty counties also increased from 0.24 in 2000 to 0.34 in 2014, an increase of $41.67 \%$. Thus, we suggest that special attention should be paid to reducing income inequity during targeted poverty alleviation to ensure sustainable development of the APTZNC.
\end{abstract}

Key words: Argo-Pastoral Transitional Zone in Northern China; poverty gap index; poverty line; income inequity; targeted poverty alleviation measures; sustainable development 